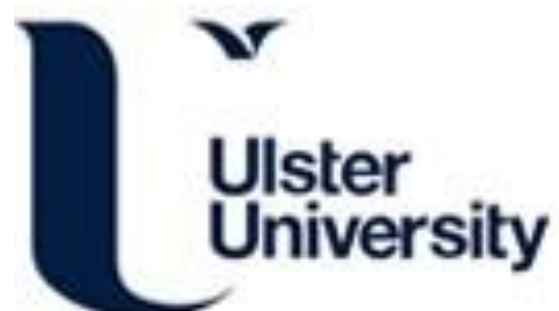

\section{Sedimentation at River Mouths bounded by Coastal Structures: A Case Study along the Emilia-Romagna Coastline, Italy}

Grottoli, E., Cilli, S., Ciavola, P., \& Armaroli, C. (2020). Sedimentation at River Mouths bounded by Coastal Structures: A Case Study along the Emilia-Romagna Coastline, Italy. Journal of Coastal Research (Special Issue), 95(SI), 505-510. https://doi.org/10.2112/S195-098.1

Link to publication record in Ulster University Research Portal

Published in:

Journal of Coastal Research (Special Issue)

Publication Status:

Published (in print/issue): 17/06/2020

DOI:

10.2112/SI95-098.1

\section{Document Version}

Publisher's PDF, also known as Version of record

\section{General rights}

Copyright for the publications made accessible via Ulster University's Research Portal is retained by the author(s) and / or other copyright owners and it is a condition of accessing these publications that users recognise and abide by the legal requirements associated with these rights.

\section{Take down policy}

The Research Portal is Ulster University's institutional repository that provides access to Ulster's research outputs. Every effort has been made to ensure that content in the Research Portal does not infringe any person's rights, or applicable UK laws. If you discover content in the Research Portal that you believe breaches copyright or violates any law, please contact pure-support@ulster.ac.uk. 


\title{
Sedimentation at River Mouths bounded by Coastal Structures: A Case Study along the Emilia-Romagna Coastline, Italy
}

\author{
Edoardo Grottoli ${ }^{\dagger}$, Silvia Cilli ${ }^{\ddagger}$, Paolo Ciavola $^{\ddagger}$, and Clara Armaroli ${ }^{{ }^{*}}$ \\ 'School of Geography and \\ Environmental Sciences \\ Ulster University \\ Coleraine, BT52 1SA Northern \\ Ireland, United Kingdom \\ *Department of Physics and \\ Earth Sciences \\ University of Ferrara \\ Ferrara 44122, Italy
}
§Scuola Universitaria
Superiore IUSS Pavia
Pavia 27100, Italy

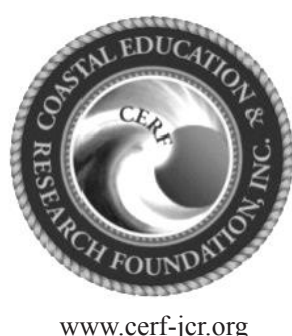

ABSTRACT
Grottoli, E.; Cilli, S.; Ciavola, P., and Armaroli, C., 2020. Sedimentation at river mouths bounded by
coastal structures: A case study along the Emilia-Romagna coastline, Italy. In: Malvárez, G. and Navas,
F. (eds.), Global Coastal Issues of 2020. Journal of Coastal Research, Special Issue No. 95, pp. 505-510.
Seville (Spain), ISSN 0749-0208.

www.JCRonline.org

Beach retreat in the Emilia-Romagna coast, facing the north Adriatic Sea, is well-known since decades and several factors are behind this phenomenon: a scarcity of natural sediment supply by rivers, natural and anthropogenic subsidence, and a strong urbanization of the coastal zone. Several bedload measurement campaigns in one representative river of the Ravenna province (Savio River) have been carried out since 2017. At the same time, seasonal surveys of bathymetry were undertaken at the river outlet to correlate changes in sedimentation with river input. The river mouth is constrained by artificial embankments that possibly funnel out sediment offshore during river floods. However, monitoring of bedload transport correlated with bathymetric changes between July 2017 and November 2018 still found a positive budget of almost 5000 cubic meters. Local authorities in Ravenna are planning to dredge 20000 cubic metres from the river mouth to supply small nourishments outside the studied coastal cell. According to the measurements of bathymetric changes, the Savio mouth will need almost six years to recover, assuming the occurrence of a particularly efficient rate of sediment transport, like the one observed in the monitored period. Notably, the analysed period included a very large river flood that could overshadow the modal sediment transport operated by the river. Furthermore, with deepening of the mouth, the two villages adjacent to the outlet are likely to become more exposed to sea flooding, due to the propagation of surges inside the river mouth. The paper concludes that dredging activities should be reconsidered in view of the precarious equilibrium of the system.

ADDITIONAL INDEX WORDS: River bedload sediment transport, beach erosion, submerged delta, sand dredging.

\section{INTRODUCTION}

In the current context of the Anthropocene epoch, rivers in the developed world have changed their characteristics as a consequence of damming, water resource exploitation and sediment dredging (Syvitski, 2018). After centuries of mismanagement, many deltas are now critically eroding at a global scale, causing an increase in vulnerability to flooding and shoreline retreat (Besset et al., 2019). This aspect is even more dramatic for Mediterranean deltas, where the present geomorphology is largely a product of a complex long-term relationship between nature and human development (Anthony et al., 2014). However, an unresolved aspect remains: the role of smaller deltaic systems in providing sediment input to semi-enclosed basins like the Adriatic Sea. According to Milliman et al. (2106), 75\% of the sediment input in this basin comes from small mountain systems on the eastern border (e.g. Montenegro, Albania, Greece), as well as, in a limited way, from rivers of central Italy along the western edge of the

DOI: 10.2112/SI95-098.1 received 31 March 2019; accepted in revision 13 February 2020

*Corresponding author: clara.armaroli@iusspavia.it

${ }^{\circ}$ Coastal Education and Research Foundation, Inc. 2020 basin. The scenario is quite different in the northern part of the Adriatic Italian territory, where rivers flow on coastal plains that have been heavily modified by man. This is the case of the EmiliaRomagna region, where the Savio River is located.

Data on river sediment discharge in the northern Adriatic is scarce and only refers to large systems like the Po River (Milliman et al., 2016). However, these datasets generally refer only to suspended sediment loads; bedload information is actually missing for river sections in alluvial plains close to the mouths. Notable exceptions are the Reno (Preciso et al., 2012) and Fiumi Uniti rivers (Billi et al., 2017), in the study region where the Savio is located. The current paper has the following aims: (i) to evaluate bedload sediment transport through direct measurements during river floods; (ii) to identify bedload sediment input at the river mouth, identifying moments of effective sediment transport; (iii) to quantify the sediment budget of the river mouth; (iv) to propose a short to medium term sustainable management strategy, considering the local demand of sediment for beach replenishments. 


\section{Field Site Description}

The Savio River is located in the Emilia-Romagna Region (northern Italy, facing the Adriatic Sea) and flows from the Apennines to the central part of the regional coastline (Figure 1). Low sandy beaches, stretching over $130 \mathrm{~km}$, characterise the coast. The coast is urbanized and artificially protected for $60 \%$ of its length by hard structures.

The Savio River has a catchment of $647 \mathrm{~km}^{2}$. Like other rivers in Italy, the river experienced large human interventions that modified its channel, levees and catchment characteristics. Land use change, starting from the end of WWII, in mountain and hilly areas, has reduced the sediment input, as observed in the nearby Reno River by Preciso et al. (2012). The diversion of channels from their original paths, as well as the construction of dams, sluice gates, sills and other hydraulic works, has significantly reduced sediment transport, leading to a shortage of sand delivery to the coast (Billi et al., 2017).

The river outlet is located along a highly urbanized coastal sector (Figure 1, inset), corresponding to the town of Lido di Savio. The mouth's central axis direction is between $30^{\circ} \mathrm{N}$ and $40^{\circ} \mathrm{N}$. The adjacent beaches are protected by breakwaters and are regularly artificially replenished. Like other rivers in the region, the riverbed is suspended at an elevation higher than the surrounding alluvial plain, as dikes for centuries have prevented inundation and sediment accumulation on the floodplain. The

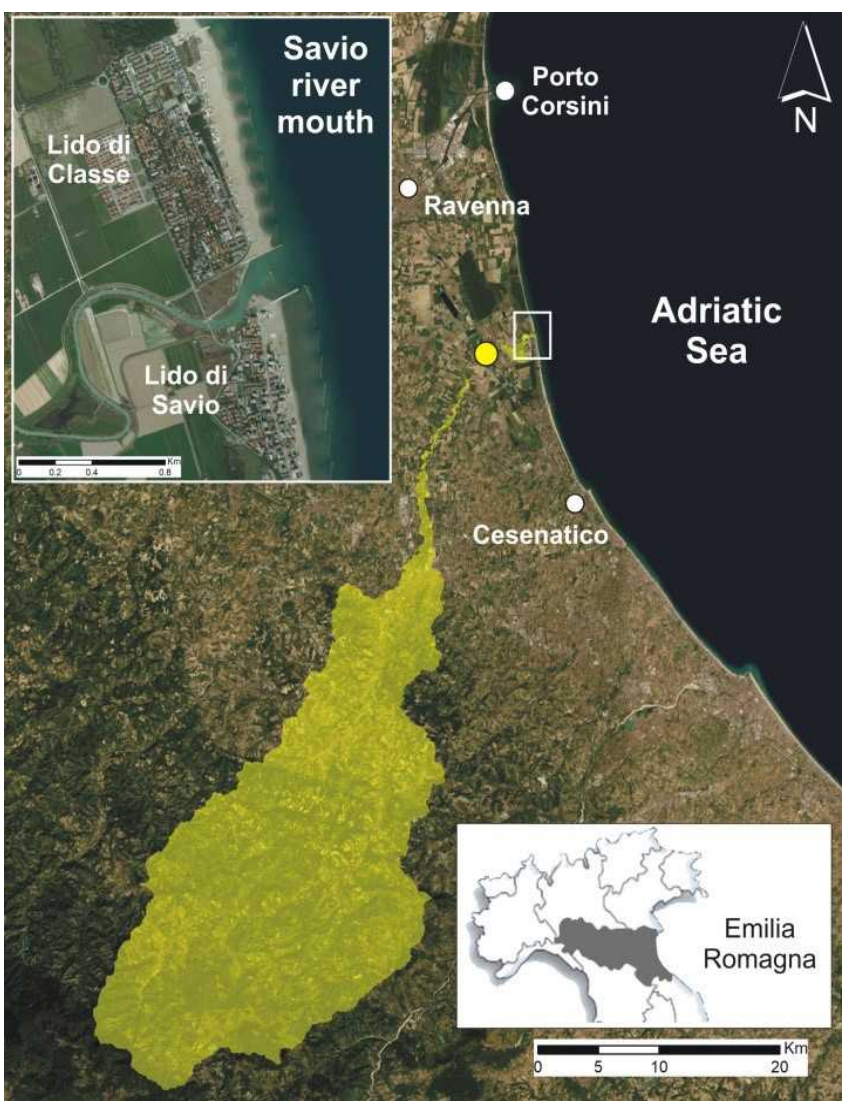

Figure 1. Catchment of the Savio River (in yellow) and characteristics of its mouth (the inset image represents the area inside the white rectangle). The yellow dot indicates the location of the road bridge used for the measurements. river course is developed into narrow meanders. An exception is the final part of the river, close to the mouth, where it becomes wider. This causes sediment accumulation inside the mouth, in an area that is equally influenced by river floods as well as marine storms. However, the outlet is not able to freely change its shape, being constrained by artificial embankments.

The beaches of the Emilia Romagna region experience chronic erosion due to longshore sediment transport interruption produced by artificial structures, subsidence and sediment starvation (Perini et al., 2016). Natural subsidence is exacerbated by groundwater and natural gas extraction at the coast near Ravenna, with a subsidence rate of almost $2 \mathrm{~cm} /$ year (Antonellini et al., 2019; Perini et al., 2017; Taramelli et al., 2015). Regional authorities mitigate beach erosion through regular nourishments with sands taken from quarries, alongshore deposits, including navigation channel dredging, as well as offshore sands.

The wave regime is of low energy (mean $\mathrm{Hs} \sim 0.5 \mathrm{~m}$; main storm directions are NE and SE) and the tidal excursion is microtidal ( $0.9 \mathrm{~m}$ range at spring tides). Storm surge, generated mainly by SE winds, is a key component leading to beach erosion and inundation of the hinterland (1-in-10 year return period surge level is $\sim 1 \mathrm{~m}$; Masina and Ciavola, 2011).

\section{METHODS}

River bedload sediment transport, water discharge and morphology of the submerged part of the river mouth were studied between July 2017 and June 2019 through the collection of several information: (i) sampling of bedload sediments during river floods; (ii) measurements of river depth, water level and current velocity; (iii) collection of hydrological data from gauges close to the mouth; (iv) seasonal bathymetry of the outlet; (v) identification of the characteristics of sea storm events (Hs, Tp, direction, duration) and sea levels in the analysed period.

\section{Bedload Sampling and River Discharge}

Bedload and suspended sediments were collected at a section located $3.5 \mathrm{~km}$ from the mouth of the river (Figure 1). The section was selected because of the availability of recent topobathymetries and due to appropriate logistical conditions for fieldwork activities. Its location, in a rectilinear segment of the river, is inland enough to avoid tidal influence. The section is equipped with a radar hydrometer installed by the regional environment protection agency (ARPAe). The measurements were carried out from a bridge using a crane with a Helley-Smith sampler (squared intake of $7.6 \times 7.6 \mathrm{~cm}$; weight $29.5 \mathrm{~kg}$; nylon sampling bag with a mesh size of $0.100 \mathrm{~mm}$ ) and a standard current velocimeter (type AA, USGS). Thirteen river flood events were measured in the period between February 2017 and May 2019. The data collected for each river flood were analysed to find empirical relationships between water levels and discharge values as well as between discharge values and volumes of bedload sediment transport. The threshold discharge value able to trigger bedload sediment transport was also evaluated from the same data.

\section{Hydrological Data}

Hydrological data are regularly collected by ARPAe using a network of radar hydrometers located along regional rivers. The data are published in hydrological yearly reports in the form of synthetic parameters, such as mean daily discharge, yearly 
characteristic discharges (i.e., $\mathrm{Q}_{\max }, \mathrm{Q}_{\text {mean }}, \mathrm{Q}_{\min }$ ) and discharge duration. The full dataset between 30 June 2017 and the end of November 2018 of measured water levels registered every 30 minutes was collected and analysed, in order to calculate sediment transport for each river flood that occurred within the time interval between the bathymetric surveys.

\section{Bathymetries}

Three bathymetric surveys were carried out at the mouth of the river, including a portion of the final river course. The surveys were carried out on 6 July 2017, 17 May and 14 November 2018 (Figure 2).

A single beam echo sounder (Ohmex - SonarMite) was used acquiring soundings at $2 \mathrm{~Hz}$, with an accuracy of $\pm 0.025 \mathrm{~m}$. The echo sounder was connected to an RTK-GNSS antenna (Trimble R6) working in VRS mode with an accuracy of $\pm 0.05 \mathrm{~m}$. Crossshore and alongshore survey lines were measured from shallow water to a depth of $-5 \mathrm{~m}$.

Wavy lines were surveyed within the river banks. Outliers and spikes were manually removed from the ouput files and a five cells smoothing was performed before interpolation. A digital elevation model (DEM) was built for each survey with an horizontal resolution of $2 \mathrm{~m}$ and a vertical precision of $10 \mathrm{~cm}$ (Figure 2). The DEMs were then compared (computation of the Dem of Difference, DoD) to evidence sedimentation and erosion patterns and the total volume variation in the submerged area.

In order to consider only the area where longshore sediment transport occurred (i.e., from the average breaking depth of storm waves), each DoD was computed between the mouth and $-4 \mathrm{~m}$ below m.s.l. (Figure 2).

\section{Sea Storm Events}

Sea storms that occurred in the period between June 2017 and November 2018 were identified following the methodology of Armaroli et al. (2012). The wave dataset was recovered from the ARPAe buoy at Cesenatico (Figure 1). Sea levels were measured by the Porto Corsini tide gauge of ISPRA-RMN (Figure 1). The

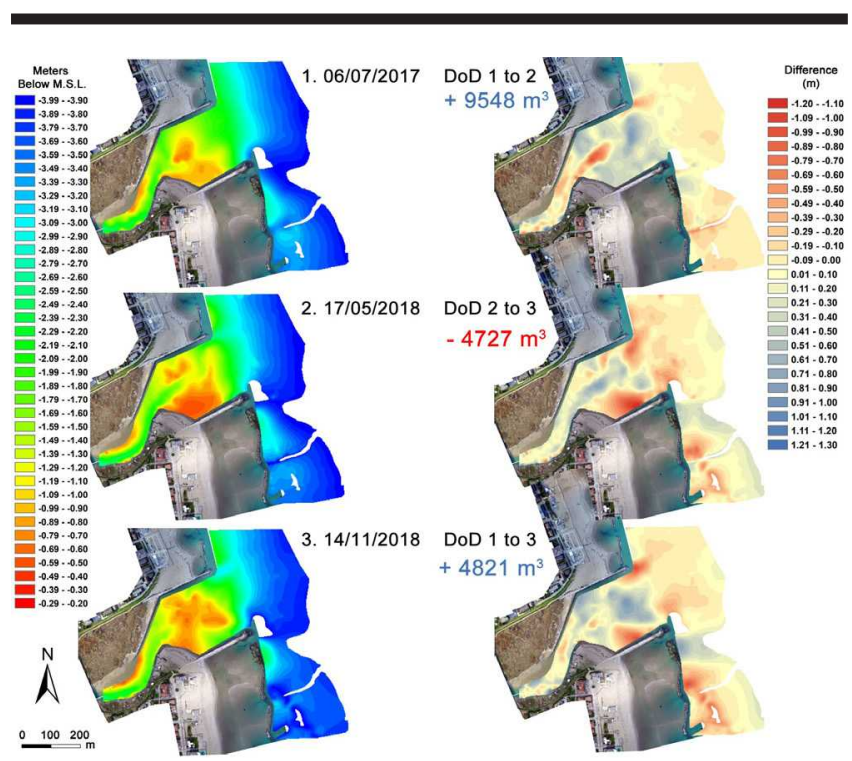

Figure 2. DEMs and DoDs of bathymetric surveys of the Savio river outlet. To note that the dates in the figure are in the format $\mathrm{dd} / \mathrm{mm} / \mathrm{yyyy}$. storms and their main characteristics (Table 1) were used to evaluate the marine forcing components acting at the mouth of the river and on alongshore sediment transport. The energy of each storm was calculated using Equation (1):

$$
E=\int_{t_{1}}^{t_{2}} H_{S \text { max }}^{2} d t
$$

Table 1. Sea storms characteristics between 2017 and 2018. The cells in grey correspond to the period between the first and second bathymetry.

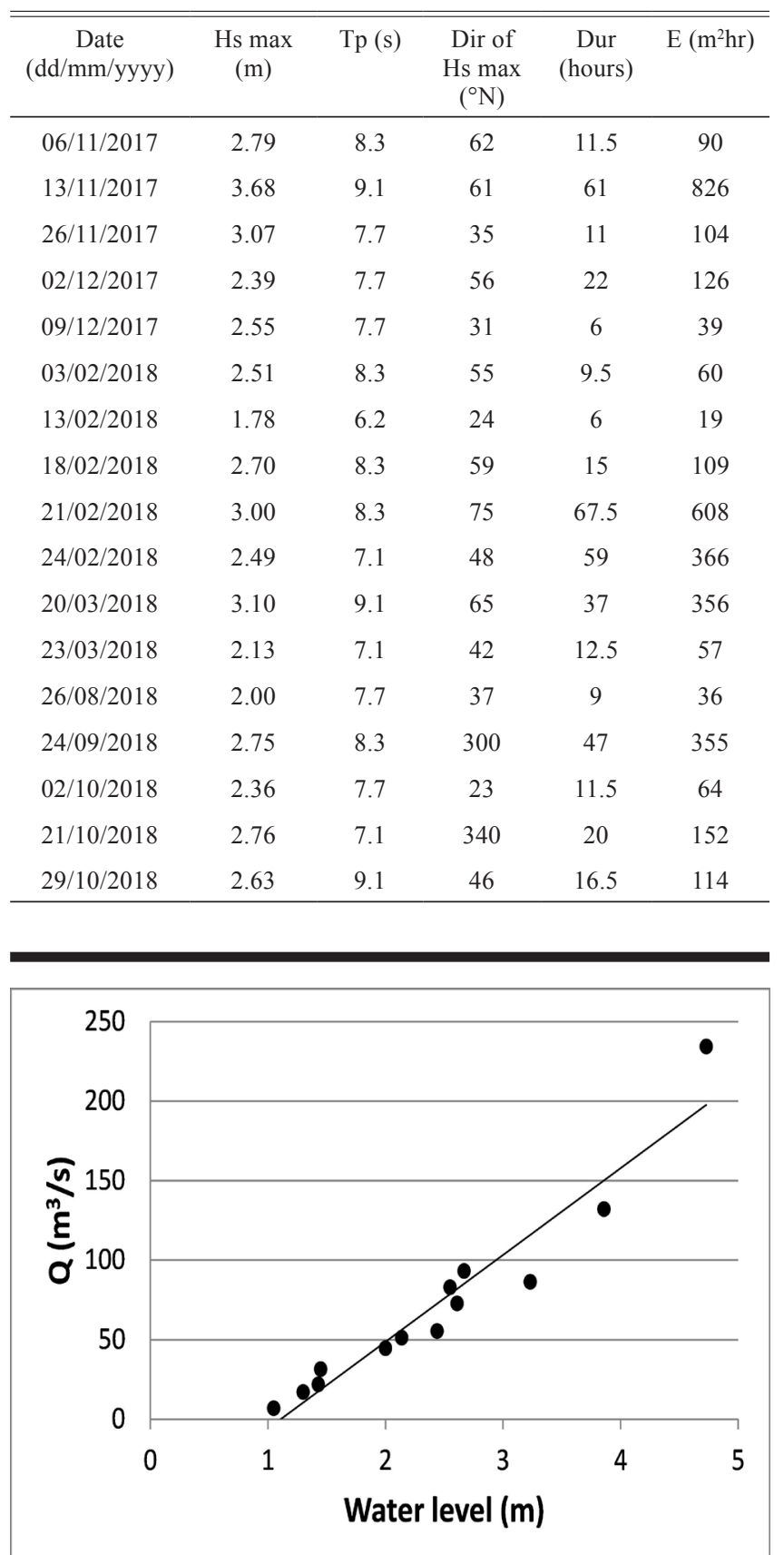

Figure 3. Relationship between measured river water levels (referred to MSL) and measured discharge values $(\mathrm{Q})$. 
Where $\mathrm{H}_{\mathrm{s} \max }$ is the maximum significant wave height measured during the storm, while the time interval $t_{1}-t_{2}$ represents the duration of the storm.

\section{RESULTS}

The hydraulic data collected during fieldwork activities (water level, flow velocity, channel depth) were used to build an empirical relationship that relates the river water level and the discharge (Figure 3).

The relationship (Equation 2) was used to calculate the discharge values of all the river floods in the analysed period (i.e., including also the ones not measured during fieldwork activites):

$$
Q=54.556 \cdot W L-60.443
$$

where WL is the water surface elevation measured by the radar hydrometer. The correlation coefficient $\left(\mathrm{R}^{2}\right)$ is 0.92 . The field measurements were used to define the threshold discharge able to trigger bedload sediment transport: this was identified as 22 $\mathrm{m}^{3} / \mathrm{sec}$.

Similarly, the measured discharges (Q) and measured bedload sediment transport volumes $\left(\mathrm{Q}_{\mathrm{b}}\right)$ were related using Equation (3) (Figure 4):

$$
Q_{b}=0.0000087638 \cdot Q^{3.1584}
$$

The correlation coefficient $\left(\mathrm{R}^{2}\right)$ is 0.72 .

The total sediment volume transported by the river in the period between the first and the last bathymetric survey was calculated with the following procedure: (i) application of Equation (2) to build a timeseries of discharge values (Q); (ii) application of Equation (3), considering only discharge values equal to or exceeding the threshold defined above (i.e., 10 out of 13 surveys), to produce a timeseries of $\mathrm{Q}_{b}$; (iii) summation of $\mathrm{Q}_{b}$ values in the analysed period. The results indicate a total volume of transported sediment equal to $6306 \mathrm{~m}^{3}$. Notably, all the sediment

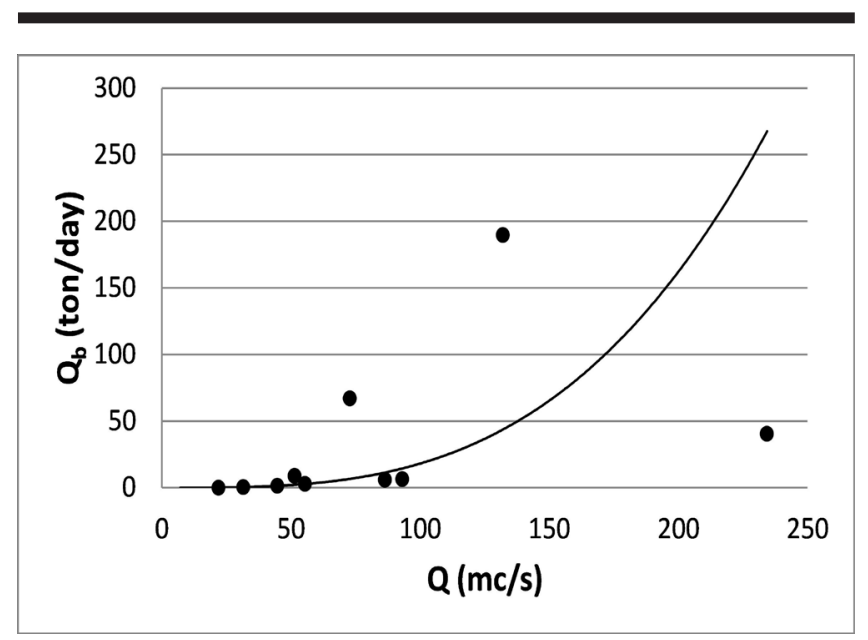

Figure 4. Exponential relationship between the measured discharge values (Q) and the measured volumes (tons per day) of bedload sediment transport $(\mathrm{Qb})$. was transported between the first and second bathymetric survey, because after April 2018 no major river floods occurred.

The analysis of the bathymetries shows that there was an overall sediment accumulation in the submerged river mouth of $\sim 5000 \mathrm{~m}^{3}$, with sedimentation between the first and the second bathymetry $\left(\sim 10000 \mathrm{~m}^{3}\right)$ and erosion between the second and the third one $\left(\sim 5000 \mathrm{~m}^{3}\right.$; Figure 2$)$.

The DoD generated by the comparison between the second and first survey shows sediment accumulation constrained between the dykes and the formation of a deeper channel in the central part of the river outlet.

The second comparison evidences the infilling and accumulation of sediment in the central channel, a significant erosion in the areas adjacent to the dykes and offshore of the breakwaters. Overall, the comparison shows accretion but there are hotspots of erosion too, likely generated by the presence of protection structures (erosion at the head of breakwaters and jetties, and in the gaps between successive breakwaters). Seventeen sea storms were identified with prevailing directions from the north-east. The time frame between the first and second survey was characterized by the occurrence of 12 sea storms over 5 months (November 2017 - March 2018), including the most intense of the series (13 November 2017; Table 1).

The second period includes five storms over a time span of three months (August - October 2018). Storm energy in the first period

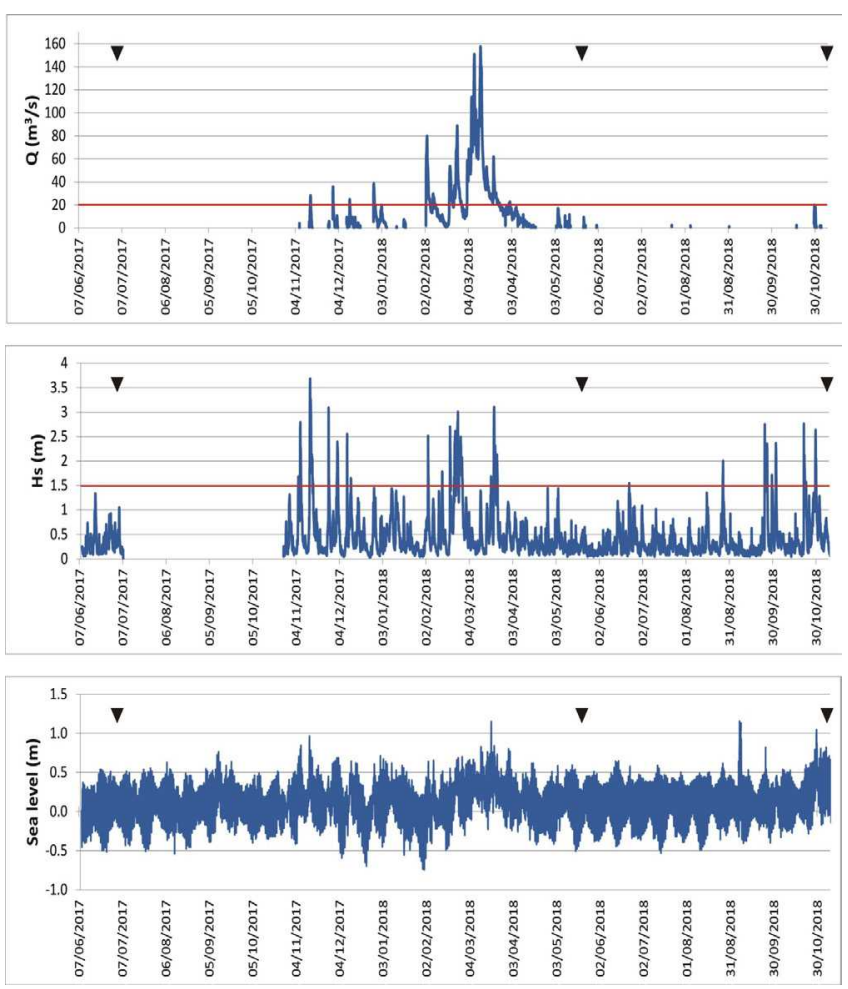

Figure 5. Timeseries of river discharge values (top panel), wave height (mid panel) and sea levels (bottom panel) between June 2017 and November 2018. The black triangles indicate the three bathymetries. The red line in the upper graph indicates the threshold discharge able to trigger bedload transport. The red line in the middle graph indicates the threshold wave height used to identify the sea storms. 
(Equation 1) was mainly from the east while in the second period it was from the north. If we consider the whole period, wave energy shows a balance between storm directions, with a slight prevalence from the east, meaning that the northward longshore sediment transport was prevalent.

Some of the river floods occurred at the same time as sea storm events (or very close in time) in the period between February and March 2018, but the two most intense river flood events occurred on 8 and 12 March 2018 when sea conditions were of low energy (Figure 5).

\section{DISCUSSION}

Overall, the sediment budget of the river mouth shows accretion in both the analysed periods (i.e., between the three bathymetric surveys). The relationship between sediment transport operated by the river and accretion of the submerged part of the mouth is partially reflected by the data, because the volumes of bedload transport are not completely comparable to the sedimentation at the outlet. As the bedload measuring section is located not far from the mouth, the assumption is that most of the sediment transported by the river is able to reach and accumulate at the mouth, as well as to enter into the littoral sediment budget. The data highlight that a decrease in the river input is reflected by an erosional trend within the confined area of the river mouth. Part of the sediment likely remains trapped in the section of the river from the measuring bridge and the mouth, being this sector characterised by the presence of meanders and bars. Additionally, sills along the final section of the river course could trap sediment and prevent it from reaching the river mouth. The river banks are well vegetated (woody arboreal and shrub vegetation), thus they could be an additional source of sediment trapping. An important aspect that should be taken into account is that, because of the presence of the river bars, meanders, woody vegetation and sills, the sediment could take a longer time, than the one analysed, to reach the outlet.

The sediment accumulation on the submerged part of the mouth is due to input from the river. The role of tidal currents could also have contributed to shape the submerged part of the outlet and sedimentary patterns evidenced by the DoDs (Figure 2). After the period of significant river floods in March 2018 (Figure 5), seven sea storms occurred and could have enhanced the erosion of the sediment deposited at the mouth. However, the data evidence that the input from the river does not accumulate at the mouth or that the sedimentation is very limited with respect to the transported sediment. Furthermore, the deposited sand is removed from marine currents soon after as it reaches the outlet. It should be underlined that the volumes of bedload transport may not reflect the modal conditions of the river, because a very large flood occurred in the analysed period. Therefore, under average transport conditions, the sediment accumulation at the mouth would result to be even more limited than the one presented here. Considering the sediment volume accumulated at the river mouth in one year $\left(\sim 3616 \mathrm{~m}^{3}\right)$ and the planned dredging operations by the local municipality $\left(\sim 20000 \mathrm{~m}^{3}\right)$ the river should recover the present sediment stock in almost six years. It is remarked that this assumption has to be carefully considered before undertaking dredging. The current study takes into account a short time frame, which represents a limiting factor in portraying medium term coastal processes.

\section{CONCLUSIONS}

The current work outlined the need to carry out simultaneous measurements of river bedload and mouth morphology to properly describe the behavior of such small deltaic systems. This work represents a protocol which is hardly performed at many river mouths but it is hoped that it will become a standard before dredging is undertaken. From a managerial point of view, only limited sediment dredging should be undertaken at this site, instead of the $20000 \mathrm{~m}^{3}$ which are planned by the local municipality of Ravenna to replenish beaches which are located several kilometers northwards. An inappropriate action may deprive the sediment budget of the area for a period of at least six year and possibly longer, increasing tidal propagation inside the lowest reach of the river.

\section{ACKNOWLEDGEMENTS}

This work is part of the $\mathrm{PhD}$ thesis of S. Cilli, to be submitted to the EMAS programme of the University of Ferrara. We are grateful to all the people who helped in the field and in particular to E. Duo and F. Droghetti. We also are deeply indebted with P. Billi for introducing us into bedload measurements and we thank L. Schippa for the discussions on hydraulic measurements.

\section{LITERATURE CITED}

Antonellini, M.; Giambastiani, B.M.S.; Greggio, N.; Bonzi, L.; Calabrese, L.; Luciani, P.; Perini, L., and Severi, P., 2019. Processes governing natural land subsidence in the shallow coastal aquifer of the Ravenna coast, Italy. Catena, 172, 7686.

Anthony, E.J.; Marriner, N., and Morhange, C., 2014. Human influence and the changing geomorphology of Mediterranean deltas and coasts over the last 6000 years: From progradation to destruction phase? Earth-Science Reviews, 139, 336-361.

Armaroli, C.; Ciavola, P.; Perini, L.; Calabrese, L.; Lorito, S.; Valentini, A., and Masina, M., 2012. Critical storm thresholds for significant morphological changes and damage along the Emilia-Romagna coastline, Italy. Geomorphology, 143-144, 34-51.

Besset, M.; Anthony, E.J., and Bouchette, F., 2019. Multi-decadal variations in delta shorelines and their relationship to river sediment supply: An assessment and review. Earth-Science Reviews, 193, 199-219.

Billi, P.; Salemi, E.; Preciso, E.; Ciavola, P., and Armaroli, C., 2017. Field measurement of bedload in a sand-bed river supplying a sediment starving beach. Zeitschrift für Geomorphologie, 61(3), 207-223.

Masina, M. and Ciavola, P., 2011. Analisi dei livelli marini estremi e delle acque alte lungo il litorale ravennate. Studi Costieri, 18, 87-101.

Milliman, J.; Bonaldo, D., and Carniel, S., 2016. Flux and fate of river-discharged sediments to the Adriatic Sea. Advances in Oceanography and Limnology, 7(2), 106-114.

Perini, L.; Calabrese, L.; Salerno, G.; Ciavola, P., and Armaroli, C., 2016. Evaluation of coastal vulnerability to flooding: comparison of two different methodologies adopted by the Emilia-Romagna region (Italy). Natural Hazards and Earth System Sciences, 16, 181-194.

Perini, L.; Calabrese, L.; Luciani, P.; Olivieri, M.; Galassi, G., and Spada, G., 2017. Sea-level rise along the Emilia-Romagna coast (Northern Italy) in 2100: scenarios and impacts. Natural Hazards and Earth System Sciences, 17, 2271-2287. 
Preciso, E.; Salemi, E., and Billi, P., 2012. Land use changes, torrent control works and sediment mining: Effects on channel morphology and sediment flux, case study of the Reno River (Northern Italy). Hydrological Processes, 26, 1134-1148.

Syvitski, J., 2018. Foreword. In: Syvitski J., Kelly J., Scarpino P., Berry H., and Meybeck M. (Eds.), Rivers of the Anthropocene, Oakland, California: University of California Press, Xi-Xiv.
Taramelli, A.; Di Matteo, L.; Ciavola, P.; Guadagnano, F., and Tolomei, C., 2015. Temporal evolution of patterns and processes related to subsidence of the coastal area surrounding the Bevano River mouth (Northern Adriatic) Italy. Ocean and Coastal Management, 108, 74-88. 